Nazir, M. 2003. Metode penelitian. Jakarta: Ghalia Indonesia.

Qardhawi, Yusuf. 1996. Tauhidullah dan Fenomena Kemusyrikan. Surabaya: Pustaka Progresif.

Sabiq, As Sayyid. 1992. Islamuna. Beirut-Libanon: Dar al Fikr.

Sugiono. 2005. Memahami Penelitian Kualitatif. Bandung: Alfabeta.

Syaodih, Nana. 2005. Metode Penelitian Pendidikan. Bandung: Rosdakarya.

Tim Penyusun. 2008. Kamus Besar Bahasa Indonesia, Pusat Bahasa Departemen Pendidikan Nasional. Jakarta: Gramedia Pustaka Utama.

Wikipedia. tt. Suku Jawa. http://id.wikipedia.org/wiki/suku_jawa [14, Mei, 2013].

Zakariya, Abi; Muhyiddin, Al Hafidz dan an Nawawi, Yahya Sarf. 1994. Riyadus Shalihin. Beirut-Libanon: Dar al Fikr. 


\title{
KONTRIBUSI "PEMMALI" TANAH BUGIS BAGI PEMBENTUKAN AKHLAK
}

\author{
Muh. Rusli dan Rakhmawati \\ Institut Agama Islam Negeri (IAIN) Sultan Amai Gorontalo \\ email:muhammadruslii@yahoo.com
}

\begin{abstract}
Pemmali culture has firmly staked in Bugis cultural traditions through speech and is believed to shape children's morals to anticipate the negative effect of the surroundings. Parents introduced pemmali to their children from an early age before they get formal education. Selection of appropriate phrases or sentences easily understood by younger children is the key for parenting success in transmitting noble values. An easy word, for instance, ulcers, worms, bad luck, insurgent, hit by something or kidnapped by demon, lack of sustenance, orphaned, struck by lightning, do not get a mate, and the other can affect children's way of thinking so that they accept their parent's advice. The consequence of pemmali is very effective in influencing the thinking and behavior of Bugis children to adulthood. Pemmali reflects noble values inherited from generation to generation. It contains the value of prudence warns for the children to act, customary manners in daily life; appreciating parents, teachers, and human beings; managing time, building mental and physical health and creativity of the children, and others. The concept of pemmali is a main choice for Bugis parents to anticipate the negative effects of globalization era. It expresses the local values as part of national culture.
\end{abstract}

Budaya pemmali telah mengakar dalam tradisi suku Bugis melalui budaya tutur dan diyakini mampu membentuk akhlak anak serta mengantisipasi pengaruh negatif lingkungannya. Pemmali diperkenalkan orang tua Bugis kepada anak-anaknya sejak dini sebelum mereka mengenal dunia pendidikan formal. Pemilihan kata atau kalimat yang pas dan mudah dipahami anak usia dini merupakan kunci kesuksesan orang tua Bugis dalam mewariskan nilai-nilai luhur dan akhlak yang baik kepada anak-anaknya. Kata bisulan, cacingan, celaka, durhaka, ditabrak atau diculik setan, kurang rezeki, orang tua meninggal, disambar petir, tidak mendapatkan jodoh, dan lainnya merupakan kata yang 
mudah mempengaruhi cara berpikir mereka sehingga mau menerima nasehat orang tuanya. Konsekuensi pemmali sangat efektif mempengaruhi cara berpikir dan perilaku anak Bugis sampai dewasa. Sebagai budaya, pemmali syarat akan nilai-nilai luhur yang diwariskan secara turun temurun. Di dalamnya terkandung nilai kehati-hatian bagi anak dalam bertindak, adat sopan santun dalam menjalani kehidupan sehari-hari; penghargaan kepada orang tua, guru, dan sesama manusia; manajemen waktu, membangun kesehatan mental, fisik dan kreatifitas anak, dan lainnya. Kini konsep pemmali menjadi pilihan utama orang tua Bugis dalam mengantisipasi derasnya pengaruh negatif era globalisasi pada anaknya. Ini merupakan ekspresi kearifan lokal sebagai bagian budaya nasional.

Keywords: Pemmali culture, local values, Bugis, moral

\section{Pendahuluan}

Kebudayaan merupakan sistem pengetahuan yang meliputi sistem ide atau gagasan yang terdapat dalam pikiran manusia, sehingga dalam kehidupan sehari-hari kebudayaan itu bersifat abstrak. Sedangkan perwujudan kebudayaan adalah benda-benda yang diciptakan oleh manusia sebagai makhluk yang berbudaya, berupa perilaku dan benda-benda yang bersifat nyata, misalnya pola-pola perilaku, bahasa, peralatan hidup, organisasi sosial, religi, seni, dan lain-lain, yang kesemuanya ditujukan untuk membantu manusia dalam melangsungkan kehidupan bermasyarakat. Dengan demikian, kebudayaan dalam suatu masyarakat merupakan sistem nilai tertentu yang dijadikan pedoman hidup oleh warga yang mendukung kebudayaan tersebut. Karena dijadikan kerangka acuan dalam bertindak dan bertingkah laku, maka kebudayaan cenderung menjadi tradisi dalam suatu masyarakat. Tradisi adalah sesuatu yang sulit berubah karena sudah menyatu dalam kehidupan masyarakat. Oleh karena itu, tampaknya tradisi sudah terbentuk sebagai norma yang dibakukan dalam kehidupan masyarakat (Ghazali, 2011: 32).

Bangsa Indonesia adalah bangsa yang kaya akan budaya lokalnya. Hanya saja nasib budaya lokal mengalami pasang surut seiring ketidakperdulian pemerintah untuk mengelolanya secara arif dan bijaksana. Di era orde Baru, nasib budaya lokal cukup memprihatinkan, banyak budaya lokal yang dimiliki oleh berbagai etnik di negara ini tidak dipublikasikan oleh negara atas pertimbangan mengancam "budaya nasional" dan keutuhan bangsa, serta alasan beberapa di antara budaya lokal tersebut bertentangan dengan ajaran agama resmi. Hal tersebut merupakan potret tindakan yang 
mengaburkan kekayaan budaya bangsa.

Angin segar bagi budaya lokal mulai berhembus ketika era reformasi digulirkan. Reformasi memberikan ruang yang luas bagi munculnya keanekaragaman budaya lokal di ruang publik dan didukung oleh sistem otonomi daerah. Pemerintah Daerah sudah melirik budaya lokal sebagai kekayaan daerah. Hanya saja tantangan baru muncul di era otonomi daerah yakni budaya lokal yang dipublikasikan hanyalah aspek budaya lokal yang menguntungkan pariwisata (baca: eksploitasi budaya). Pemerintah Daerah belum menunjukkan adanya upaya maksimal untuk memberikan keleluasaan bagi seluruh pemilik budaya mengekspresikan budayanya masing-masing. Alih-alih menepis habis ragam budaya atau meleburkannya menjadi satu, kebijakan multikulturalis berusaha menciptakan kebudayaan nasional lebih sebagai sebuah mozaik kultural, bukan sebuah entitas tunggal dan utuh (Budiman dan Nurkhoiron, 2005: 8).

Terlepas dari problem yang masih melingkupi budaya lokal, setidaknya kesadaran masyarakat mulai meningkat untuk menghargai dan mengekspresikan seluruh nilai-nilai budaya lokalnya tanpa merasa tertekan dari pihak manapun. Adanya kesadaran budaya ditandai oleh: 1) Pengetahuan akan adanya berbagai kebudayaan suku bangsa yang masingmasing mempunyai jati diri beserta keunggulan-keunggulannya, 2) Sikap terbuka untuk menghargai dan berusaha memahami kebudayaan suku-suku bangsa di luar suku bangsanya sendiri, dengan kata lain, kesediaan untuk saling kenal, 3) Pengetahuan akan adanya berbagai riwayat perkembangan budaya di berbagai tahap masa silam, dan 4) Pengertian bahwa di samping merawat dan mengembangkan unsur-unsur warisan budaya, kita sebagai bangsa Indonesia yang bersatu juga sedang mengembangkan sebuah kebudayaan baru, yaitu kebudayaan nasional, yang dapat mengambil sumber dari manapun, yaitu dari warisan budaya kita sendiri maupun dari budaya asing yang dianggap dapat meningkatkan harkat bangsa (Sedyawati, 2007: 330).

Budaya lokal kini memiliki kesempatan untuk tampil mengambil peran dalam kehidupan masyarakat. Budaya lokal atau yang lazim disebut kearifan lokal mengacu pada berbagai kekayaan budaya yang tumbuh dan berkembang dalam sebuah masyarakat dikenal, dipercayai, dan diakui sebagai elemen-elemen penting yang mampu mempertebal kohesi sosial di antara warga masyarakat (Abdullah dan Mujid, 2008: 7).

Kearifan lokal kini dianggap sebagai salah alternatif dalam menyelesaikan 
problem masyarakat termasuk dalam pembentukan akhlak anak sejak dini. Dewasa ini, akhlak anak semakin memprihatinkan, mulai dari kasus pelanggaran hukum adat istiadat setempat, perkelahian antar sekolah, narkoba, pencurian, dan kejahatan lainnya. Untuk itu, dituntut peran serta seluruh komponen bangsa termasuk budayawan untuk merumuskan kembali model pembentukan akhlak anak sejak dini. Salah satu aspek yang dapat dimanfaatkan adalah kearifan lokal yang selama ini tumbuh dan berkembang dalam kehidupan sehari-hari masyarakat.

Tanpa menafikan kearifan lokal yang dimiliki oleh setiap suku yang ada di Indonesia, penulis memfokuskan pada salah satu aspek kearifan lokal suku Bugis yakni budaya "pamali" yang dalam konstruk bahasa Bugis disebut pemmali. Pemmali diyakini oleh suku Bugis memiliki nilai pembentuk akhlak sejak dini. Penelitian ini menggunakan pendekatan fenomenologi.

\section{Kearifan Lokal Masyarakat Bugis}

Orang Bugis adalah salah satu dari berbagai suku bangsa di Asia Tenggara dengan populasi lebih dari empat juta orang. Mereka mendiami bagian barat daya pulau Sulawesi. Mereka termasuk ke dalam rumpun keluarga besar Austronesia (Pelras, 2006: 1). Seiring perkembangan zaman dan budaya rantau (sompe') yang dimilikinya, suku ini dapat ditemui di berbagai tempat di Indonesia bahkan sampai di beberapa negara tetangga. Sebagai suku yang mayoritas beragama Islam dengan tingkat keberagamaan yang tergolong tinggi, tidak menjadikan suku tersebut mencampakkan nilai-nilai budaya yang selama ini diwariskan secara turun temurun. Bahkan, suku Bugis dikenal sebagai suku yang kental akan budaya dan adat istiadatnya.

Fungsi adat bagi manusia Bugis Makassar tidak sekedar mengatur tingkah laku manusia dalam kehidupan bermasyarakat, akan tetapi dia mempunyai arti yang lebih dalam lagi. Di dalam adat itu terkandung unsur kepercayaan yang hakiki dari setiap manusia kepada kekuasaan Yang Maha Tinggi yang telah menciptakan seluruh alam semesta ini. Pencipta yang kita sebut Tuhan, merupakan titik sentral dari segala-galanya. Oleh karena itu, adat yang mereka ciptakan dan telah berakar dalam kehidupan masyarakat bersumber kepada budi pekerti, moral manusiawi, dan hukum keadilan. Tiga unsur inilah yang merupakan inti atau menjiwai kehidupan adat mereka (Abdullah, 1985: 6-7).

Berbagai macam kearifan lokal yang dimiliki oleh suku Bugis, meliputi 
masalah: 1) Hati, nafsu, dan nurani, 2) Pikiran, akal, dan kecakapan, 3) kejujuran, 4) Tegas-keteguhan, 5) Bicara, 6) Usaha, pekerjaan, 7) Pria, wanita, 8) Hubungan dengan orang lain, 9) Tanggung jawab, harga diri, 10) Siri, berani, dan takut, 11) Semangat hidup, takdir, dan nasib, 12), Hati-hati, tenang, 13) Bijaksana, lapang dada, 14) Serakah dan ambisi, 15) Mengendalikan diri, 16) Balas budi, 17) Hal-hal yang baik, 18) Hal-hal yang buruk, 19) Serba-serbi, 20) Petuah-petuah (Machmud, 1994: 1-104). Rahim menambahkan dua macam kearifan lokal yang juga dimiliki suku Bugis Makassar sampai hari ini yakni siri na pacce (Rahim, 1992:168).

Reinterpretasi terhadap budaya siri na pacce merupakan hal penting untuk dilakukan. Kalau siri'i merupakan taruhan harga diri, maka harga diri tersebut harus diangkat melalui kerja keras, berprestasi, berjiwa pelopor dan senantiasa berorientasi keberhasilan. Harga diri terangkat atas dukungan rasa Pesse (Bugis) atau Pacce (Makassar), yaitu solidaritas terhadap orang lain sebagai partisipasi sosial. Pesse adalah iba hati melihat sesama yang mengalami penderitaan atau tekanan batin atas perbuatan orang lain dan sejenisnya. Siri' dan pacce adalah dua sikap moral yang menjaga stabilitas dan berdimensi harmonisasi, agar tatanan sosial atau Pangadereng (adat inti adat) berjalan secara dinamis ( Hamid, 2005: xiii).

Orang Bugis memiliki yang namanya Lontara'. Lontara' adalah manuskripmanuskrip atau catatan-catatan tertulis yang aslinya ditulis di atas daun lontar dengan menggunakan alat tajam (pena yang terbuat dari lidi dan enau), kemudian dibubuhi warna hitam pada bekas guratan-guratan. Tanda-tanda bunyi atau aksara yang dipergunakan disebut juga aksara lontara'. Manuskripmanuskrip atau catatan-catatan tertulis itu, dalam aneka ragam isinya, antara lain; 1) Paseng, 2) Attoriolong, 3) Pau-pau ri Kodong, 4) Tolo, 5) Pangaja, 6) Ulu ada, 7) Sure' Bicara Attoriolong, 8) Pau Kotika, 9) Sure' Eja, 10) Sure' Bawang (Mattulada, 1995: 16-19). Di daerah Sulawesi Selatan juga terdapat budaya dan kearifan-kearifan lokal seperti konsep sipakalebbi dalam budaya Bugis saling menghormati, sipakainge - saling mengingatkan, dan konsep solata dalam budaya Toraja (Nuh, 2005: 298).

Selain itu, terdapat salah satu aspek kearifan lokal yang dimiliki suku Bugis yang disebut "pemmali". Pemmali dapat dimaknai sebagai salah satu aspek budaya yang merupakan hasil kreativitas masyarakat dalam membangun tatanan sosial yang diadopsi dari nilai-nilai luhur yang diwariskan secara turun-temurun dari satu generasi ke generasi berikutnya. Pemmali dapat pula dimaknai sebagai bentuk kehati-hatian masyarakat dengan belajar dari masa 
lalu sehingga kejadian masa lalu tidak berulang di masa yang akan datang.

\section{Bentuk dan Nilai Budaya Pemmali}

Bagi masyarakat Bugis, budaya "pemmali" merupakan aturan tak tertulis namun sifatnya mengikat. Setiap orang tua berkewajiban (wajib secara budaya) untuk mengajarkan kepada anak-anaknya akan pesan-pesan "pemmali" sejak dini. Budaya pemmali sudah diperkenalkan kepada anak sebelum ia menginjakkan kaki di dunia pendidikan formal. Tujuan pemmali lebih pada penanaman budi pekerti atau akhlakul karimah dalam perspektif budaya. Perbuatan atau perkataan yang seharusnya dihindari terangkum dalam makna pemmali tersebut.

Pemmali mengandung unsur larangan atau pantangan hidup. Pemmali dapat dibagi dua, yakni:

\section{Pemmali yang memiliki konsekuensi yang jelas}

Pemmali yang memiliki konsekuensi yang jelas, artinya aturan yang memiliki sanksi bilamana aturan tersebut dilanggar. Sanksi berupa kecelakaan, kematian, kurang rezeki, merugi, dan lainnya. Sanksi negatif tersebut tidak hanya menimpa diri sendiri tetapi juga dapat menimpa atau berdampak kepada orang lain. Di antara pemmali yang memiliki konsekuensi yang jelas yang masih dipertahankan oleh suku Bugis sampai sekarang, adalah:

a. Tidak boleh menduduki bantal, sebab akan bisulan (Pemmali tudangi angkalungeng, nasaba' kempangekki).

Orang tua Bugis senantiasa mengajarkan kepada anaknya agar tidak duduk di atas bantal sebab bantal adalah tempatnya kepala dan kepala memiliki derajat yang tinggi dalam perspektif budaya Bugis. Jika dalam budaya Eropa memegang kepala bermakna positif namun dalam budaya Bugis justru sebaliknya. Memegang kepala dapat dimaknai penghinaan yang lazim dikenal "patuwa-tuwai". Selanjutnya, pemilihan konsekuensi "bisulan" pada dasarnya tidak memiliki hubungan langsung dengan perilaku duduk di atas bantal. Namun konsekuensi yang dipilih tersebut sangat efektif bagi anak. Hal ini menunjukkan bahwa orang tua Bugis memahami bahwa makna "bisul" sudah mampu dicerna oleh anak ketimbang menjelaskan makna "derajat kepala".

Dari larangan ini dapat disimpulkan bahwa mendidik anak dengan larangan harus sesuai dengan kemampuan dan pemahaman anak. Di samping itu, makna terdalam adalah "menempatkan sesuatu pada tempatnya". Bantal adalah tempat kepala dan bukan pantat. Menempatkan sesuatu pada tempatnya akan berbekas pada diri anak hingga dewasa 
sehingga mampu membentuk karakter anak sejak dini.

b. Tidak boleh makan ikan saja (tanpa nasi), sebab akan cacingan (Pemmali mangetta bale, nasaba' bitokekki).

Orang tua Bugis sangat melarang anaknya untuk mengkonsumsi ikan tanpa nasi sebab akan cacingan. Secara medis, konsekuensi yang ditawarkan masih membutuhkan penelitian. Namun pemilihan konsekuensi "cacingan" sangat efektif bagi anak, sebab mereka takut mengalami cacingan. Secara tidak langsung anak pun dapat belajar etika ketika makan. Lebih jauh, secara kesehatan larangan ini menghendaki pemenuhan gizi anak yang seimbang sehingga melahirkan generasi yang sehat dan cerdas.

c. Tidak boleh melakukan perjalanan bilamana orang sedang makan, sebab akan celaka di perjalanan (Pemmali tojjokka narekko manrei taue, nasaba' macilakaki).

Orang tua Bugis mengajarkan kepada anaknya untuk tidak meninggalkan orang atau keluarga yang sedang makan dengan konsekuensi celaka di perjalanan. Meskipun secara fakta belum tentu benar, namun bahasa "celaka di perjalanan" sangat efektif dalam mendidik anak untuk mematuhi aturan tersebut. Secara budaya larangan ini menghendaki penghargaan kepada orang yang sedang makan sehingga mereka tidak buru-buru makan. Di samping itu, memberikan kesempatan kepada mereka untuk dapat mengantar kepergiaannya dengan doa. Dalam tradisi Bugis, orang yang ingin bepergian harus berpamitan atau bersalaman kepada semua keluarga yang ditinggalkan, dan keluarga yang ditinggal harus mengantarnya sampai ke halaman rumah serta mendoakan keselamatannya. Dengan demikian, penghargaan, saling mengasihi, dan saling mendoakan, terangkum dalam pesan tersebut.

d. Tidak boleh menunjuk atap rumah guru kita, sebab akan durhaka (Pemmali ijello coppo bolana gurutta, nasaba' madorakaki).

Orang tua Bugis senantiasa mengajarkan kepada anaknya untuk menghargai figur guru. Jika menunjuk atap rumah seorang guru saja bermakna dosa apalagi jika membantah atau tidak mendengarkan nasehatnya. Dalam konstruk budaya Bugis, guru yang lazim disebut Gurutta merupakan sosok tauladan yang menjadi inspirasi bagi perilaku keseharian masyarakat. Dengan demikian, adat sopan santun dan penghargaan terhadap guru "mappakalebbi" telah diajarkan oleh orang tua sejak dini kepada anak-anaknya.

e. Tidak boleh kencing berdiri, sebab akan panjang kelamin (Pemmali teme 
tettong, nasaba' malampe lasomu).

Orang tua Bugis senantiasa mengajarkan kepada anaknya untuk kencing dalam posisi duduk. Konsekuensi "akan panjang kelamin" merupakan pilihan yang tepat dan mudah diterima oleh anak meskipun secara medis belum memiliki hubungan secara langsung. Kencing berdiri bertentangan dengan adat kesopanan dan ajaran agama. Dengan demikian, pesan yang terkandung di dalamnya adalah memelihara adat kesopanan dalam kehidupan sehari-hari.

f. Tidak boleh tidur pagi, sebab rezeki akan jauh (Pemmali matinro ele, nasaba' mabelai dalle'mu).

Orang tua Bugis mengajarkan kepada anaknya untuk tidak tidur pagi sebab rezeki akan jauh. Konsekuensi yang dipilih "rezeki yang jauh" sangat erat hubungannya dengan tidur pagi. Tidur pagi merupakan pola hidup yang tidak sehat dan merupakan identitas yang melekat pada orang yang malas. Orang yang malas tentu saja jauh dari penghidupan yang layak. Lebih jauh, pesan yang terkandung di dalamnya adalah pola hidup sehat dan semangat kreativitas yang tinggi yang ditandai dengan bekerja sejak pagi untuk mencari rezeki yang halal.

Dalam tradisi Bugis, penting untuk memperkenalkan dunia kerja kepada anak sejak dini sehingga ketika mereka dewasa tidak menganggur dan menunggu uluran tangan orang lain. Upaya memperkenalkan dunia kerja kepada anak yakni dengan mengikutsertakan anak untuk bekerja di sawah, kebun atau tempat orang tuanya beraktivitas.

g. Tidak boleh tidur tengkurap, sebab akan mati orang tua (Pemmali matinro moppang, nasaba' matei tomatoatta)

Orang tua Bugis melarang anaknya untuk tidur atau berbaring dalam posisi tengkurap dengan pilihan konsekuensi "orang tua akan meninggal”. Meskipun konsekuensi yang dipilih tersebut tidak berhubungan secara langsung dan membutuhkan penelitian secara medis tentang dampak tidur tengkurap namun secara budaya sangat efektif dalam membangun adat kesopanan anak. Tentu saja, setiap anak tidak ingin orang tuanya cepat meninggal diakibatkan oleh perbuatannya. Pesan yang tekandung dalam larangan tersebut adalah adat kesopanan.

h. Tidak boleh memakai baju merah ketika hujan, sebab akan disambar petir (Pemmali mabbaju cella' narekkko bosiwi, nasaba' nakennaki lette).

Orang tua Bugis melarang anaknya memakai pakaian merah ketika kilat dan guntur sebagai bentuk kehati-hatian untuk keselamatan anak. Warna merah identik dengan warna petir sehingga pakaian tersebut 
harus diganti ketika cuaca mendung. Dalam tradisi Bugis, warna merah merupakan salah satu warna favorit yang menandakan keberanian, sehingga baju warna merah sering menjadi pilihan orang tua dan anak untuk dikenakan. Lebih jauh, makna yang terkandung dalam larangan tersebut adalah orang tua Bugis menginginkan anaknya yang sementara asyik bermain untuk kembali ke rumah bilamana hujan turun. Dengan demikian, terkandung nilai kehati-hatian dalam larangan tersebut.

i. Tidak boleh melangkahi alat pikul, nanti salah pikul (Pemmali yajjulekkai lempae nasaba salah lempa ammaki).

Orang tua Bugis mengajarkan kepada anaknya untuk tidak melangkahi alat pikul sebab akan salah pikul. Salah pikul merupakan bahasa kiasan agar mereka senantiasa menjaga perilakunya dalam bergaul. Boleh jadi "salah sasaran" dapat menimpa siapa saja. Orang yang tidak seharusnya menanggung akibat dari perbuatan atau kesahalan orang lain. Untuk itu, nilai kehati-hatian dalam bergaul terangkum dalam larangan tersebut.

j. Tidak boleh bertopang dagu, sebab akan celaka (Pemmali mattula' bangi tauwe nasaba macilakai).

Orang tua Bugis mengajarkan kepada anaknya untuk tidak bertopang dagu, sebab bertopang dagu mengindikasikan orang tersebut memiliki sifat malas, santai, tidak mau bekerja, dan hanya menunggu uluran tangan orang lain. "Mattula bangi" merupakan perilaku negatif dan tidak seharusnya dilakukan menurut budaya Bugis. Mattula' bangi juga mengindikasikan sifat keangkuhan dan kesombongan yang semestinya hanya dimiliki oleh Tuhan. Tidak ada pembenaran bagi manusia untuk berlaku angkuh dan sombong dalam kehidupannya. Dengan demikian, nilai yang terkandung dalam larangan tersebut adalah menuntut kreativitas anak sejak dini dan bersikap rendah hati.

k. Tidak boleh makan menggunakan penutup sebab akan dijadikan penutup malu (Pemmali manrei passampo nasaba' mancajiki' passampo siri).

Orang tua Bugis melarang anaknya menggunakan penutup sebagai alat makan atau pengganti piring bermakna penanaman terhadap nilainilai kesopanan dan kepatutan. Orang yang menggunakan penutup sebagai alat makan mengindikasikan sifat malas untuk mengambil piring dan tentu saja tidak sedap dipandang mata.

Konsep "passampo siri" itu sendiri dalam budaya Bugis dimaknai sebagai orang yang menanggung atau menutup aib orang lain. Biasanya konsep ini digunakan ketika terjadi musibah hamil di luar nikah yang 
dialami oleh seorang gadis. Untuk menutup aib keluarga sang gadis, maka dicarikanlah laki-laki yang bersedia untuk dinikahkan dengan gadis tersebut. Laki-laki tersebut disebut passampo siri karena menutup aib keluarga perempuan.

Dengan demikian, nilai yang terkandung dalam larangan tersebut adalah adat sopan santun makan yang akan berpengaruh pada pembentukan karakter anak Bugis sejak dini. Di samping itu, bentuk kehati-hatian bagi generasi muda agar tidak terjerumus dalam pergaulan bebas yang berujung pada aib keluarga.

1. Tidak boleh menolak ajakan orang lain untuk makan meskipun hanya sedikit, sebab akan celaka (Pemmali de tomanre narekko naolliki taue namuni cedde' mua nasaba macilakaki).

Orang tua Bugis mengajarkan kepada anaknya untuk menghargai orang lain (sipakalebbi). Menolak ajakan orang lain untuk makan merupakan sifat yang kurang terpuji karena tidak menghargai niat baik orang tersebut. Budaya pun memberikan solusi bilamana kita masih kenyang ketika diajak orang untuk makan, maka seyogyanya mengambil beberapa biji nasi untuk dimakan sebagai tanda telah memenuhi ajakan tersebut. Dengan demikian, larangan ini mengandung nilai penghargaan (sipakalebbi) antara sesama manusia.

m. Tidak boleh menyisakan makanan, sebab akan durhaka (Pemmali esesa nanrewe, madorakaki).

Orang tua Bugis senantiasa mengajarkan anaknya untuk menghabiskan makanan, sebab bila tidak akan durhaka (kepada Allah SWT). Dalam konstruk nalar Bugis, mereka percaya bahwa nasi yang dimakan terdapat berkah di dalamnya. Jangan sampai berkah tersebut terbuang pada nasi yang tersisa. Jika itu terjadi, maka makanan yang masuk tidak memberikan berkah dan dapat menyebabkan manusia sakit. Tentu saja keyakinan ini sejalan dengan konsep agama, yakni dilarang membuang makanan (mubazir). Hanya saja dalam budaya Bugis bahasa mubazir diganti dengan bahasa durhaka. Bahkan, aib besar bagi orang yang membuang sisa makanan di tempat saluran air atau tempat kencing.

Menurut keyakinan suku Bugis, makanan yang terkena kencing akan menangis dan mengaduh kepada Tuhan bahwa si A atau si B telah menelantarkannya. Untuk itu, nasi tersebut meminta kepada Tuhan agar rezeki orang yang telah menelantarkannya ditahan. Dengan demikian, larangan tersebut mengandung nilai adat makan, tidak bersifat mubazir, 
dan mencari keberkahan Tuhan dalam segala aktivitas kehidupan.

n. Tidak boleh bermain pada hari menjelang magrib, sebab akan ditabrak setan (pemmali maccule ko magaribiwi, nasaba' naleppoki setang).

Orang tua Bugis senantiasa mengawasi perilaku anaknya termasuk kapan dan dimana anak boleh bermain. Pola pengawasan tersebut dimaksudkan untuk mendisiplinkan anak dan memahami manajemen waktu. Magrib merupakan waktu beribadah kepada Tuhan, sehingga anak harus berhenti bermain dan kembali ke rumahnya untuk beribadah bersama orang tuanya. Pemilihan konsekuensi "setan" dianggap tepat karena anak takut kepada setan sehingga tidak ada alasan baginya untuk tetap bermain di saat magrib telah tiba. Pesan yang terkandung di dalam larangan tersebut adalah pendidikan disiplin dan manjamen waktu bagi anak sejak dini.

o. Tidak boleh ngambek atau menyendiri, sebab akan diculik setan (Pemmali to magelli, nasaba' nalaki talimpau)

Dalam konstruk budaya Bugis, setan digambarkan sebagai sosok makhluk yang tinggi besar dan hitam. Setan dikenal dengan nama "Talimpau". Orang tua Bugis mengajarkan kepada anaknya bahwa orang yang selalu ngambek kemudian menyendiri akan diculik oleh talimpau dan akan dibawa jauh dari rumah.

Dalam realitas kehidupan suku Bugis, penculikan anak oleh talimpau adalah hal yang masuk akal dan mereka telah menyaksikan kejadian tersebut berulang kali. Pada umumnya, anak yang diculik dibawa jauh dan disembunyikan di tempat gelap. Masyarakat Bugis percaya bahwa anak yang diculik akan ditawari untuk memakan kue yang terbuat dari kotoran kerbau, setelah ia makan maka anak tidak mampu bicara untuk beberapa saat. Untuk menghentikan penculikan tersebut, masyarakat menabur gendang tapis beras yang dipercaya mampu membebaskan anak dari genggaman setan tersebut. Dengan demikian, larangan ini mengandung makna pendidikan bagi anak untuk tidak menyendiri dan marah.

p. Tidak boleh mencari kutu bagi anak perempuan di tangga, sebab jodohnya akan jauh (Pemmali makkita utu ana' makkunraie ri addengengnge, nasaba' mabelai lakkainna).

Orang tua Bugis mengajarkan kepada anaknya untuk tidak mencari kutu di tangga. Maklum konstruk rumah suku Bugis mayoritas rumah panggung sehingga terkadang anak duduk santai di tangga. Larangan mencari kutu di tangga merupakan bentuk kehati-hatian orang tua 
kepada anaknya agar mereka tidak terjatuh dari tangga. Mencari kutu di tangga dapat pula menghalangi orang yang ingin naik ke rumah, dan dapat mendatangkan fitnah bagi orang yang lewat serta merupakan perilaku yang tidak sopan secara budaya. Adapun pemilihan konsekuensi "jauh dari jodoh" sangat efektif bagi anak perempuan karena mereka takut tidak mendapatkan jodoh kelak ketika mereka dewasa. Dengan demikian, larangan tersebut mengandung makna kehati-hatian dan adat kesopanan bagi anak.

\section{Pemmali yang tidak memiliki konsekuensi yang jelas}

Pemmali yang tidak memiliki konsekuensi yang jelas artinya larangan atau pantangan yang tidak dijelaskan orang tua Bugis kenapa hal tersebut dilarang dan apa dampak negatifnya bila dilanggar. Orang tua hanya mengatakan hal tersebut merupakan ketetapan dari orang tua secara turun temurun dan menurut ketentuan budaya harus dipatuhi. Interpretasi terhadap makna pemmali jenis ini diserahkan sepenuhnya kepada anak untuk direnungkan maknanya. Di antara pemmali jenis ini yang masih ada dalam masyarakat Bugis sampai sekarang;

a. Tidak boleh menumpahkan air panas ke tanah (Pemmali bollang wai pella ri tanae).

b. Tidak boleh menjahit malam (Pemmali majjai wenni).

c. Tidak boleh menyapu malam (Pemmali masserring wenni).

d. Tidak boleh berucap kata "mungkin" (Pemmali mappau gare').

e. Tidak boleh mengeluh (Pemmali toli maddareke).

f. Tidak boleh menyindir orang lain (Pemmali ripareresi padatta rupa tau).

g. Tidak boleh sembarang bicara (Pemmali kapau-pau).

h. Tidak boleh mengadu domba (Pemmali mappalettu sala)

i. Tidak boleh lewat depan orang tanpa permisi (Pemmali lalo di olona taue nade' nappetabe').

Meskipun larangan di atas tidak disertai dengan konsekuensi yang harus ditanggung bila dilanggar. Namun, bagi suku Bugis pada dasarnya mengandung makna yang dalam. Misalnya: (a) Tidak boleh menumpahkan air panas ke tanah (Pemmali bollang wai pella ri tanae), kalimat tersebut mengandung makna kehati-hatian yaitu dapat mengenai orang atau binatang peliharaan yang kebetulan lewat di bawah rumah. Maklum struktur rumah panggung yang dimiliki oleh suku Bugis memungkinkan orang atau binatang lalu lalang di bawahnya. Larangan ini dapat pula dimaknai sebagai bentuk kehati-hatian agar 
tidak merusak kesuburan tanah. Di samping itu bentuk kehati-hatian jangan sampai tertumpah dan mengenai diri sendiri, b) Tidak boleh menjahit malam (Pemmali majjai wenni), kalimat tersebut mengandung makna kehati-hatian agar tidak tertusuk jarum karena kondisi ruangan yang gelap, c) Tidak boleh menyapu malam (Pemmali masserring wenni), kalimat tersebut mengandung makna kehati-hatian jangan sampai menyapu suatu barang yang berharga. Pada dasarnya, larangan aktivitas seperti menjahit atau menyapu malam sangat erat kaitannya dengan aturan waktu pekerjaan. Bagi masyarakat Bugis, waktu siang adalah waktu untuk beraktivitas sedangkan malam hari adalah waktu untuk istirahat. Untuk itu, pekerjaan yang seharusnya dikerjakan pada siang hari tidak boleh dikerjakan pada malam hari. Manajemen waktu terangkum dalam larangan tersebut, d) Tidak boleh berucap kata "mungkin" (Pemmali mappau gare'), kalimat tersebut mengandung makna kehati-hatian dalam berbicara.

Kata "mungkin" boleh jadi benar dan boleh jadi salah. Kata mungkin lahir dari ketidakyakinan atau prasangka. Misalnya saja, pada orang pertama masih menggunakan kata mungkin ketika menceritakan kepada orang kedua, selanjutnya orang kedua atau ketiga tidak lagi mengatakan "mungkin" sehingga prasangka telah berubah menjadi fakta. Dengan demikian, larangan mengucapkan kata "mungkin" dimaksudkan agar terhindar dari kebohongan, fitnah dan lainnya, e) Tidak boleh mengeluh (Pemmali toli maddareke), kalimat tersebut mengandung makna semangat yang tinggi, kerja keras, dan tidak menyalahkan orang lain atau keadaan. Bagi suku Bugis, sikap suka mengeluh hanyalah dimiliki oleh pribadi yang lemah dan tidak memiliki prinsip hidup yang jelas, f) Tidak boleh menyindir orang lain (Pemmali ripareresi padatta rupa tau), kalimat tersebut mengandung makna etika pergaulan. Menyindir orang lain akan melahirkan kebencian dan permusuhan serta memutus tali silaturrahmi (sumpulolo), g) Tidak boleh sembarang bicara (Pemmali kapau-pau), kalimat tersebut bermakna kehati-hatian untuk memilih kata yang baik dan benar dalam bertutur kata, sebab ucapan yang telah keluar dari mulut bukan lagi milik kita menurut pemahaman budaya Bugis.

Manusia yang baik adalah manusia yang tutur katanya mengandung kebenaran, h) Tidak boleh mengadu domba (Pemmali mappalettu sala), kalimat tersebut mengandung makna etika untuk senantiasa berkata benar, i) Tidak boleh lewat depan orang tanpa permisi (Pemmali lalo di olona taue nade' nappetabe'), kalimat tersebut mengandung makna penghormatan kepada sesama manusia, atau menghormati yang tua dan menyayangi yang muda. Konsep mappetabe' merupakan aturan adat tidak tertulis namun sifatnya mengikat. Bagi orang yang tidak merealisasikan konsep tersebut dianggap de' nappakkeade' (orang yang tidak 
tahu adat) dan mendapat penilaian negatif di masyarakat.

Berdasarkan paparan sebelumnya, dapat disimpulkan bahwa budaya pemmali Bugis syarat akan makna pembentukan akhlak karimah. Budaya tersebut telah diajarkan orang tua Bugis sejak dini melalui budaya tutur (lisan). Di antara nilai-nilai tersebut adalah: Pertama, menempatkan sesuatu pada tempatnya yang dapat disepadankan dengan konsep keadilan. Kedua, penghargaan (sipakalebbi sipakatau) kepada orang lain, guru, dan orang tua. Ketiga, memelihara adat kesopanan. Keempat, memelihara kesehatan mental dan fisik anak. Kelima, membangun kreativitas anak yang meliputi pendidikan pola pergaulan yang baik, pendidikan disiplin dan manajemen waktu bagi anak. Keenam, kehati-hatian dalam segala tindakan dan lainnya.

Nilai-nilai tersebut telah mengakar dalam kehidupan masyarakat Bugis dan dipertahankan sampai sekarang. Setiap orang tua memiliki beberapa pemmali yang menjadi warisan keluarganya secara turun temurun. Hal tersebut berdampak pada karakter anak ketika mereka sudah dewasa. Hanya saja, orang tua Bugis mengakui bahwa tantangan terbesar yang dihadapi sekarang adalah derasnya pengaruh globalisasi dan informasi sehingga nilai-nilai tersebut perlu upaya keras agar tetap terpatri dalam diri anak.

\section{Simpulan}

Suku Bugis merupakan suku yang syarat akan berbagai macam kearifan lokal yang diwariskan secara turun temurun dari satu ke generasi ke generasi berikutnya. Di antara kearifan lokal yang masih ada sampai sekarang adalah budaya pemmali. Budaya tersebut diyakini mampu membentuk akhlak anak sejak dini. Meskipun bentuk pemmali tidak selamanya memiliki konsekuensi yang jelas, namun bagi orang tua Bugis maknanya dapat diarahkan pada pembentukan akhlak. Di antara nilai yang terkandung dalam budaya pemmali tersebut adalah; Menempatkan sesuatu pada tempatnya yang dapat disepadankan dengan konsep keadilan; Penghargaan (sipakalebbi sipakatau) kepada orang lain, guru, dan orang tua.; Memelihara adat kesopanan (mappakkeade'); Memelihara kesehatan mental dan fisik anak; Membangun kreatifitas Anak; Pendidikan pola pergaulan yang baik; Pendidikan disiplin dan manajemen waktu bagi anak; Kehati-hatian dalam segala tindakan dan lainnya.

Dewasa ini, penghargaan terhadap kearifan lokal seyogyanya digalakkan bagi setiap suku di Indonesia sebab perannya sangat besar dalam kehidupan masyarakat. Negara pun dituntut untuk berperan serta memberikan kontribusi nyata dalam bentuk pemberian ruang yang luas 
bagi setiap suku mengekspresikan kearifan lokal yang dimiliki dalam pentas nasional. Bahkan jika perlu menjadikan kearifan lokal yang ada sebagai budaya nasional.

\section{Daftar Pustaka}

Abdullah, Hamid, 1985. Manusia Bugis Makassar - Suatu Tinjauan Historis terhadap Pola Tingkah Laku dan Pandangan Hidup Manusia Bugis Makassar, Jakarta: Inti Idayu Press.

Abdullah, Irwan, dan Ibnu Mujib, 2008. Agama dan Kearifan Lokal dalam Tantangan Global. Cet. II; Yogyakarta: Sekolah Pascasarjana UGM dan Pustaka Pelajar.

Budiman, Hikmat dan Mochammad Nurkhoiron, 2005. Hak Minoritas - Dilema Multikuralisme di Indonesia. Jakarta: Yayasan Interseksi/The Interseksi Foundation.

Ghazali, Adeng Muchtar, 2011. Antropologi Agama - Upaya Memahami Keragaman Kepercayaan, Keyakinan, dan Agama. Cet. I; Bandung: Alfabeta.

Hamid, Abu, 2005. Siri dan Pesse'-Harga Diri Manusia Bugis, Makassar, Mandar, Toraja. Cet. II; Makassar: Pustaka Refleksi.

Mahmud, A. Hasan, 1994. Silasa - Kumpulan Petua Bugis - Makassar. Jakarta: Bakti Centra Baru.

Mattulada, 1995. Latoa - Suatu Lukisan Analitis terhadap Antropologi Politik Orang Bugis. Cet. II; Ujung Pandang: Hasanuddin University Press.

Nuh, Nuhrison M, 2005. Menelusuri Kearifan Lokal di Bumi Nusantara - Catatan Perjalanan dan Hasil Dialog Antar Pemuka Agama Pusat dan Daerah. Jakarta: Puslitbang Kehidupan Beragama.

Pelras, Christian. Manusia Bugis. Terjemahan oleh Abdul Rahman Abu, Hasriadi, Nurhady Sirimorok. Cet. I; Nalar bekerjasama dengan Forum Jakarta-Paris, EFEO, 2006.

Rahim, A. Rahman, 1992. Nilai-nilai Utama Kebudayan Bugis. Cet. III; Ujung Pandang: Hasanuddin Press.

Sedyawati, Edi, 2007. Budaya Indonesia: Kajian Arkeologi, Seni, dan Sejarah. Jakarta: PT. Raja Grafindo Persada. 